KEMAS 15 (2) (2019) 241-246
Jttp://journal.unnes.ac.id/nju/index.php/kemas

\title{
Application of Casein Phosphopeptide Isolate in Cheese as Dental Caries Prevention
}

\author{
Muhammad Muflih Fathulhuda ${ }^{1 \bowtie}$, Cindy Caroline ${ }^{1}$, Shafwah Muthmainnah ${ }^{1}$, Didah \\ Nur Faridah ${ }^{2}$ \\ ${ }^{1}$ Program Studi Teknologi Pangan, Institut Pertanian Bogor, Bogor \\ ${ }^{2}$ Departemen Ilmu dan Teknologi Pangan, Fakultas Teknologi Pertanian, Institut Pertanian Bogor, Bogor
}

\begin{tabular}{l} 
Article Info \\
\hline Article History: \\
Submitted July 2019 \\
Accepted October 2019 \\
Published November 2019 \\
\hline Keywords: \\
Casein phosphopeptide, \\
Cheese, Dental car- \\
ies, Remineralization, \\
Streptococcus mutans \\
\hline DOI \\
https://doi.org/10.15294/ \\
kemas.v15i2.20042
\end{tabular}

\section{Article Info}

Accepted October 2019

Casein phosphopeptide,

Cheese, Dental car-

ies, Remineralization,

https://doi.org/10.15294/

\begin{abstract}
Dental caries is an infectious disease that results from bacterial interactions with teeth. One of the preventive effort against dental caries is consuming foods containing a bioactive compound called casein phosphopeptide (CPP). Cheese is one of the food products that contain CPP. This study aimed to measure the potential of CPP compounds obtained from cheese protein as a preventative for dental caries. This research was conducted from April to July 2019. The method used in this study was measuring the inhibition power on the growth of bacteria causing dental caries (Streptococcus mutans) and measure the process of teeth remineralization in vitro. The results showed that the yield of crude CPP isolates obtained from commercial parmesan cheese was $16.65 \pm 2.97 \%$. CPP isolates inhibited the growth of S. mutans at concentrations of $10 \%, 15 \%$, and $20 \%$ with inhibitory zone values of $1.22 \pm 0.04 \mathrm{~cm}, 1.30 \pm 0.00 \mathrm{~cm}$, and $1.36 \pm 0.08 \mathrm{~cm}$, respectively. The application of $0.1 \mathrm{~g} \mathrm{CPP}$ isolates on tooth surface for 10 days was shown to increase tooth hardness by $28.36 \%$.
\end{abstract}

\section{Introducton}

The largest problem currently faced in the field of dental and oral health is dental caries. According to Basic Health Research (Riskesdas) in 2007-2013, the prevalence of dental caries was in Indonesia increased from $43.4 \%$ in 2007 to $53.2 \%$ in 2013 . In the same year, WHO (World Health Organization) data showed that the largest increase occurred at the age of 12 years $(13.7 \%)$ and 65 years (14.3\%). The cause for such high prevalence of dental caries is the consumption of foods containing carbohydrates (especially sugar) and the lack of attention towards oral health problems. Caries is an infectious disease that results from the interaction of bacteria with the teeth. Bacteria use food scraps as a substrate for the fermentation process and produce acids that will damage tooth enamel and cause cavities (Mustika et al., 2014).
Streptococcus mutans and Lactobacillus are reported as the main cause of caries due to their activity in fermenting sucrose into lactic acid, resulting in enamel demineralization. Such bacteria can form plaques on teeth surface which is firmly attached to teeth surface and resistant to gargling. Plaque will form on the surface of teeth and dental fillings. Plaques develop best in areas that are difficult to clean, such as the gingival edge, the proximal surface, and fissures (Ramayanti \& Purnakarya 2013). Efforts that can be made to prevent dental caries is brushing teeth properly. Tooth brushing, when done properly, can remove the remaining dirt that sticks to the teeth, therefore, preventing the growth of bacteria that cause dental caries. In addition, dental caries can also be prevented by applying materials that contains certain bioactive compounds, one of which is CPP. In the study of Kanako et al., (2005) and Maki et 
al., (2007) conducted on cattle teeth, the use of CPP paste was proven to prevent dental caries by preventing demineralization and increasing tooth remineralization.

CPP is found in relatively high amount in milk and its derivatives. Cheese is a milkderived product made by coagulating milk casein. Milk clumping is caused by the addition of acid, chymosin enzyme found in rennet or other proteolytic enzymes produced by bacteria. The addition of acid is done to reduce the $\mathrm{pH}$ to 4.5-5.4 which is the isoelectric point of milk casein. The addition of rennet to milk is done when the desired acidity has been reached so that the chymosin enzyme can work optimally. The addition of rennet is intended to agglomerate milk to form the desired curd character (Budiman et al., 2017; Sari et al., 2014). The stages of cheese production consists of pasteurizing milk, clumping casein, cutting, cooking curd, whey separation, salting, pressing, and aging. During the curing process, microbial activity results in the breakdown of carbohydrates, proteins, and fats resulting in the specific taste, aroma, and texture of each cheese (Quarto et al. 2018). Protein degradation by bacterial proteolytic enzymes will break down milk casein molecules into various bioactive peptides, one of which is CPP. The presence of CPP compounds in cheese causes cheese to have potential in prevention of dental caries. CPP is reported to prevent dental caries through two mechanisms, namely preventing demineralization of tooth enamel and inhibit the attachment of caries-causing bacteria to teeth surface (Merrit et al., 2006; Sugito et al., 2008)

Cheese consumption in Indonesia has increased from 8000 tons per year (2002) to around 19,000 tons per year (2013) (Rakhman, 2010). Today many food and beverage products in Indonesia are made from cheese and is consumed by many. The West Java Animal Husbandry Department survey results stated that $52 \%$ of the people are fond of cheese. This shows that cheese has the potential to be used as an alternative solution to prevent dental caries; therefore, study on CPP compounds in cheese is needed to measure the potential of cheese as a prevention of dental caries. Siregar (2011), Farooq et al., (2013), and Divyapriya GK et al., (2016), reported that CPP compounds in dairy products have an effect on preventing dental caries, but there has been no further research into the potential of CPP compounds in cheese. Therefore, this study was conducted with the aim of measuring the potential of CPP compounds obtained from cheese protein as a prevention of dental caries in vitro.

\section{Methods}

This research was conducted from April to July 2019. The materials used in this study include commercial parmesan cheese obtained from supermarkets, frozen dried culture of Streptococcus mutans bacteria (BCC 2760) obtained from the Bogor Veterinary Research Center, and molars obtained from Dental and Mouth Clinic. The study was conducted in three stages, namely CPP isolation, $S$. mutans inhibitory test, and dental remineralization test.

CPP isolation was carried out according to the Aranachalam and Raja (2010) method with modifications. A $6 \%$ cheese suspension was made by dissolving the cheese in distilled water and stirred using a magnetic stirrer. The sample solution's $\mathrm{pH}$ was increased using $2 \mathrm{~N} \mathrm{NaOH}$ until $\mathrm{pH} 7$ then centrifuged at $4000 \mathrm{rpm}$ for 10 minutes. $1 \mathrm{~N} \mathrm{HCl}$ was added to the supernatant to obtain a $\mathrm{pH}$ of 4.6 and then centrifuged at $4000 \mathrm{rpm}$ for 10 minutes to remove proteins and peptides that do not have a phosphate group. The supernatant from centrifugation was taken and $2 \mathrm{~N} \mathrm{NaOH}$ solution was added until the $\mathrm{pH}$ of the solution reached $7.0 .7 \%$ calcium chloride was added to the sample supernatant allowed to stand for 10 minutes at room temperature. Afterwards, $50 \%$ ethanol solution $(\mathrm{V} / \mathrm{V})$ was added to the sample and centrifuged at 4500 rpm for 15 minutes. The precipitate obtained was a CPP compound.

The inhibition testing of $S$. mutans was carried out according to the method of Mahmudah \& Atun (2017) with modifications. The CPP sample was dissolved in a $\mathrm{pH} 4.6$ buffer solution at various concentrations $(10 \%$, $15 \%, 20 \%)$. Paper blanks were soaked in each sample solution for 10 minutes then placed in a blood agar medium containing $S$. mutans culture and incubated at $37^{\circ} \mathrm{C}$ for 48 hours. The inhibition zone formed was measured using a horizontal and vertical ruler. The average 
of the measurements were calculated and the inhibition zone diameters expressed in centimeters $(\mathrm{cm})$.

Tooth remineralization test was carried out according to the method of Wiryani et al., (2016) with modifications. Tooth samples (molars) were brushed and cleaned by soaking them in disinfectant solutions. The tooth roots were separated from the crowns, and the crowns were cut vertically in mesiodistal plane. Tooth samples were immersed in carbonated solution for 3 days for demineralization. The remineralization process was carried out by applying $0.1 \mathrm{~g}$ of CPP to the teeth surface every 12 hours for 10 days. CPP-treated teeth were immersed in artificial saliva (a mixture of $0.65 \mathrm{~g}$ of potassium chloride, $0.058 \mathrm{~g}$ of magnesium chloride, $0.165 \mathrm{~g}$ of calcium chloride, $0.804 \mathrm{~g}$ of potassium hydrogen phosphate, $0.365 \mathrm{~g}$ of potassium dihydrogen phosphate, $2 \mathrm{~g}$ of carboxymethyl cellulose, and 1 liter of water). The positive control used was commercial toothpaste while the negative control used was teeth without CPP treatment. Tooth hardness testing was done before and after the remineralization process using the Vickers Hardness Tester (Future-tech FM810) with a $200 \mathrm{gf}$ test load for 10 seconds at two indentation points. Hardness value was calculated according to a predetermined formula and stated in Hardness Vickers (HV) units.

\section{Result and Discussion}

CPP isolation results from commercial parmesan cheese obtained a yield of $16.65 \pm$ $2.97 \%$. The isolates obtained were white and paste-shaped rough isolates as shown in Figure
1. CPP is a group of peptides derived from casein, which is the largest constituent protein component in milk. The maximum solubility of $\mathrm{CPP}$ is at $\mathrm{pH} 4.6$ and it does not dissolve well at pH 7 (Pinto et al., 2012; Arunachalam et al., 2010). These properties distinguish CPP from proteins or other groups of peptides found in cheese.

Generally, CPP is produced by enzymatic hydrolysis of casein (Pinto et al., 2012). In the cheese manufacturing process, $\mathrm{CPP}$ is formed in large amount at curing stage. During curing, cheese protein will undergo hydrolysis and produce bioactive peptides with small molecular weights. The curing time of the cheese will determine the amount of CPP contained in the cheese. The longer the duration of curing, the larger the amount of CPP (Korhonen, 2009).

According to curing duration, cheese is divided into three types, namely soft cheese, medium cheese, and hard cheese. Hard cheese has a longer curing time and therefore highest CPP content. Parmesan cheese is one type of hard cheese with relatively high CPP content. Pinto et al., (2012) stated that there are 23 types of CPP in parmesan cheese with molecular weights between $0.8-4 \mathrm{kDa}$.

The inhibitory test result of CPP isolates and fluorinated toothpaste against $S$. mutans bacteria is presented in Figure 1. The test results showed that CPP isolates were able to inhibit the growth of $S$. mutans. CPP isolates produce inhibition zones greater than fluorinated toothpaste at the same concentration with values of $1.22 \pm 0.04 \mathrm{~cm}$ and $1.16 \pm 0.07 \mathrm{~cm}$, respectively. Fluoride toothpaste inhibits the growth of $S$. mutans by inhibiting the action

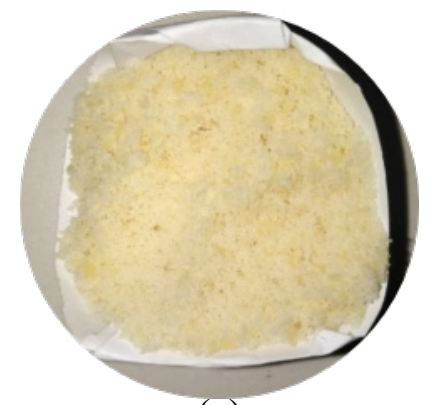

(a)

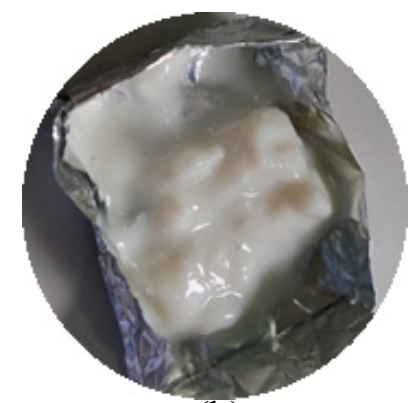

(b)

Figure 1.(a) Commercial Parmesan Cheese, (b) Caseine Phosphopeptide Isolate 


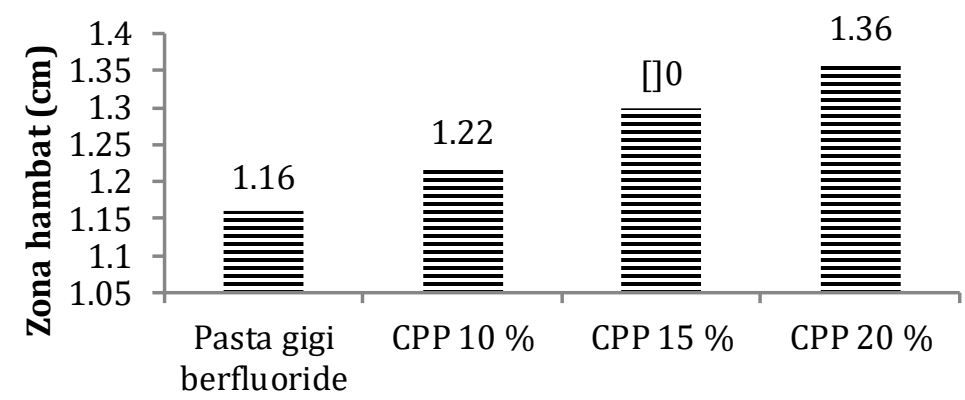

Jenis sampel

FIGURE 2. Inhibitory Zone Measurement of Streptococcus mutans

Table 1. Increase in Tooth Hardness After Treatment

\begin{tabular}{lll}
\hline \multirow{2}{*}{ Treatment } & Hardness $(\mathrm{HV})$ \\
\cline { 2 - 3 } & Before remineralization & After remineralization \\
\hline No treatment (control) & $325.3 \pm 17.1$ & $331.6 \pm 36.8$ \\
Fluoridated Toothpaste treatment & $309.6 \pm 4.5$ & $338.4 \pm 13.4$ \\
CPP treatment & $307.1 \pm 0.3$ & $394.2 \pm 43.7$ \\
\hline
\end{tabular}

Source: Primary Data, 2019

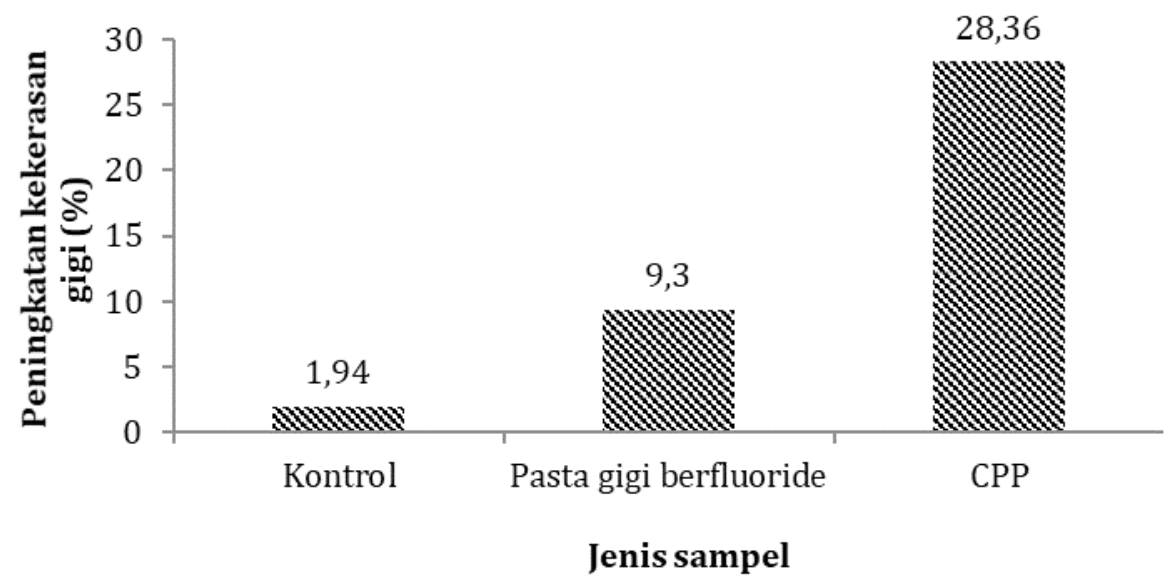

Figure 3. Percentage of Increase in Tooth Hardness

of enolase enzyme and the active protontransport ATPase enzyme, whereas the enzyme works in the process of glycolysis. Inhibition of the two enzymes causes disruption of bacterial metabolic activity (Sinaredi et al., 2014).

The higher the concentration of CPP isolates used, the greater the inhibition zone produced. CPP isolates with concentrations of $15 \%$ and $20 \%$ produced inhibitory zones of $1.30 \pm 0.00 \mathrm{~cm}$ and $1.36 \pm 0.08 \mathrm{~cm}$, respectively. According to Zhao et al., (2016), CPP can act as both bactericidal and bacteriostatic against cariogenic bacteria especially at high free calcium concentrations. The mechanism of CPP in inhibiting $S$. mutans growth starts with electrostatic interactions between CPP molecules and anionic molecules in the cell membrane of $S$. mutans. This interaction causes disruption of $S$. mutans growth (Pinto, 2009). CPP also plays a role in reducing $S$. mutans adhesion by inhibiting their adhesion to the tooth surface (Siregar, 2011). 
The result of tooth remineralization test is presented in Table 1. The result of dental hardness test showed that untreated dental samples tend to have the same hardness before and after the remineralization process, whereas teeth treated with CPP isolates and fluoridated toothpaste showed increased tooth hardness. The use of CPP isolates increased tooth hardness three times higher than fluoride toothpaste, with an increase in the percentage of hardness $28.36 \%$ and $9.30 \%$, respectively (Figure 3 ). This shows that CPP isolates was more effective in increasing teeth remineralization compared to fluoride toothpaste. This is because CPP plays a role in preventing demineralization and increasing tooth remineralization. Prevention of tooth demineralization occurred through stabilization of Amorph Calcium Phosphate (ACP) to form multiphosphoseryl sequences. CPP binds to ACP and prevents calcium and phosphorus ions dissolution. CPP concentrates ACP on tooth surfaces and in biofilms, so as to maintain tooth mineral saturation and prevent tooth demineralization (Thakkar et al., 2017; Zhao et al., 2016). CPP aids remineralization of teeth by localizing ACP from the teeth and increasing the concentration of calcium phosphate, which will turn into free calcium and phosphate ions reservoir. These conditions serve to prepare tooth enamel in receiving calcium and phosphate ions to enhance remineralization process of the teeth (Siregar, 2011; Walsh, 2005).

\section{Conclusions}

Casein phosphopeptide obtained from commercial parmesan cheese has a yield of $16.65 \pm 2.97 \%$. CPP isolates obtained was shown to inhibit the growth of one of the main bacteria that cause dental caries, namely $S$. mutans, and enhance teeth remineralization. The result showed that CPP isolates were effective in preventing dental caries.

\section{Acknowledgement}

We would like to express our gratitude towards Ministry of Research, Technology and Higher Education for the research fund granted for Student Creativity Program year 2019.

\section{References}

Arunachalam, K.D., \& Raja, R.B., 2010. Isolation and Characterisation of CPP (Casein Phosphopeptides) from Fermented Milk.
Journal of Food Science, 4 (4): 167-175.

Budiman, S., Hadju, R., Siswosubroto, S.E., Rembet, G.D.G., 2017. Pemanfaatan Enzim Rennet dan Lactobacillus plantarum YN 1.3 terhadap pH, Curd, dan Total Padatan Keju. Jurnal Zootek, 37 (2): 321-328.

Divyapriya, G.K., Yavagal, P.C., Veeresh, D.J., 2016. Casein Phosphopeptide-Amorphous Calcium Phosphate in Dentistry: An Update. International Journal of Oral Health Science, 6 (1): 18-25.

Farooq, I., Moheet, I.A., Imran, Z., Farooq, U., 2013. A Review of Novel Dental Caries Preventive Material: Casein PhosphopeptideAmorphous Calcium Phosphate (CPP-ACP) Complex. King Saud University Journal of Dental Sciences, 4: 47-51.

Kanako, Y., Masashi, M., Toshiki, T., Hirohiko, I., Keith, M.B., 2006. Effect of CPP-ACP Paste on Mechanical Properties of Bovine Enamel as Determined by An Ultrasonic Device. Journal of Dentistry, 34: 6-230.

Korhonen H. 2009. Milk-Derived Bioactive Peptides: From Science To Applications. Journal of Functional Foods, 1 (2009): 177-187.

Mahmudah, F.L., \& Atun, S., 2017. Uji Aktivitas Antibakteri dari Ekstrak Etanol Temukunci (Boesenbergia pandurata) terhadap Bakteri Streptococcus Mutans. Jurnal Penelitian Saintek, 22 (1): 59-66.

Maki, O., Kanako, Y., Toshiki, T., Hirohiko, I., Takayuki, W., Atsushi, I., Susumu, A., Masashi, M., 2007. Effect of CPP-ACP Paste on Tooth Mineralizatio: An FE-SEM Study. Journal of Oral Science, 49 (2): 115-120.

Mustika, M.D., Carabelly, A.N., Cholil. 2014. Insidensi Karies Gigi pada Anak Usia Prasekolah di TK Merah Mandiangin Martapura. Jurnal Kedokteran Gigi, 2 (2): 200-204.

Merrit, J., Fengxia, Qi., Wenyuan. 2006. Milk Helps Build Strong Teeth and Promotes Oral Health. Journal of the California Dental Association, 5 (34): 361-365.

Pinto, G., 2009. Casein Phosphopeptides as Possible Nutraceuticals for Functional Foods. University of Naples Federico II.

Pinto, G., Caira, S., Cuollo, M., Lilla, S., Chianese, L., Addeo, F., 2012. Bioactive Casein Phosphopeptides in Dairy Products as Nutraceuticals for Functional Foods. Milk Protein. In Tech.

Quarto, M., Nitride, C., Ferranti, P., Mauriello, R., Garro, G., Stasio, M.D., Volpe, M.G., Ferrazzano, G.F., Chianese, L., 2018. Peptidomic Study in Vitro And in Vivo 
Phosphopeptide Release During The Chewing of Gum Fortified with A Commercial Casein Hydrolysate. International Dairy Journal, 79 (2018): 78-84.

Rakhman, E., 2010. Variasi Lama Pemeraman Keju Susu Kerbau (Bos Bubalis) Melalui Fermentasi Rhizopus oryzae terhadap Sifat Organoleptik. Skripsi. Bandung: Universitas Pendidikan Indonesia.

Ramayanti, S., \& Purnakarya, I., 2013. Peran Makanan terhadap Kejadian Karies Gigi. Jurnal Kesehatan Masyarakat, 7 (2): 89-93.

Riset Kesehatan Dasar [Riskesdas],. 2013. Riset kesehatan dasar 2013.

Sari, N.A., Sustiah, A., Legowo, A.M., 2014. Total Bahan Padat, Kadar Protein, dan Nilai Kesukaan Keju Mozarella dari Kombinasi Susu Kerbau dan Susu Sapi. Jurnal Aplikasi Teknologi Pangan, 3 (4): 152-156.

Sinaredi, B.R., Pradopo, S., Wibowo, T.B., 2014. Daya Antibakteri Obat Kumur Chlorhexidine, Povidone Iodine, Fluoride Suplementasi Zinc Terhadap, Streptococcus mutans Dan Porphyromonas gingivalis. Dental Journal, 47 (4): 211-214.

Siregar, D., 2011. Peranan Kasein dalam Pencegahan Karies Gigi. Dentika Dental Journal, 16 (2): 197-202.

Sugito, F.S., Djoharnas, H., Darwita, R.R., 2008. Relationship Between Breastfeeding and Early Childhood Caries Severity of Children Under Three Years Old in DKI Jakarta. Makara Kesehatan, 12 (2): 87-92.

Thakkar, P.J., Badakar, C.M., Hugar, S.M.,
Hallikerimath, S., Patel, P.M., Shah, P., 2017. An in Vitro Comparison of Casein Phosphopeptide-Amorphous Calcium Phosphate Paste, Casein PhosphopeptideAmorphous Calcium Phosphate Paste with Fluoride and Casein PhosphopeptideAmorphous Calcium Phosphate Varnish on the Inhibition of Demineralization and Promotion of Remineralization of Enamel. Journal of Indian Society of Pedodontics and Preventive Dentistry, 35 (4): 312-316.

Walsh, L.J., 2005. Anticariogenic Actions of Milk and Cheese Products, and Their Clinical Application. ADA News Bulletin. (16 September 2005).

World Health Organization [WHO]. 2013. World health statistics 2013.

Wiryani, M., Sujatmiko, B., Bikarindrasari, R., 2016. Pengaruh Lama Aplikasi Bahan Remineralisasi Casein PhosphopeptideAmorphous Calcium Phosphate Fluoride (CPP-ACPF) terhadap Kekerasan Email. Majalah Kedokteran Gigi Indonesia, 2 (3): 141-146.

Zhao, I.S., Mei, M.L., Burrow, M.F., Lo, E.C., Chu, C., 2016. Prevention of Secondary Caries Using Silver Diamine Fluoride Treatment and Casein Phosphopeptide-Amourphous Calcium Phosphate Modified Glass-Ionomer Cement. Journal of Dentistry, 57: 38-44. 